\title{
VERSITA
}

Ekológia (Bratislava)

Vol. 32, No. 3, p. 277-282, 2013

doi:10.2478/eko-2013-0024

\section{SERBIAN SPRUCE (Picea omorica/Panc./Pu rkyne) VARIABILITY IN THE ARTIFICIAL POPULATIONS IN SERBIA}

\author{
VASILIJE ISAJEV ${ }^{1}$, VERA LAVADINOVIĆ ${ }^{1}$, ALEKSANDAR LUČIĆ ${ }^{2}$, LJUBINKO \\ RAKONJAC $^{2}$ \\ ${ }^{1}$ Faculty of Forestry, Kneza Višeslava 1, Belgrade, Serbia; e-mail: dule78@hotmail.com \\ ${ }^{2}$ Institute of Forestry, Kneza Višeslava 3, Belgrade , Serbia
}

\begin{abstract}
Isajev V., Lavadinović V., Lučić A., Rakonjac L.J.: Serbian spruce (Picea omorca /Panc./ P u rkyne) variability in the artificial populations in Serbia. Ekológia (Bratislava), Vol. 32, No. 3, p. 277-282, 2013.

A great part of the genetic variation and the potentials of Serbian spruce natural populations have been incorporated in several plantations in the Western Serbia at the site Quercetum fraineto-cerris s.l., Salicetum fragillis s.l and Pinetum nigre s.l. and in other similar occurrences In this way, it becomes much more available for the research and future utilization. The intensive research of the plantations started by the classification of trees into phenogroups which were considered to be significant for forestry and horticulture. The differences between flowering years, plantations and individual trees in the regularity and abundance of micro- and macro-strobiles are major indicators $f$ genetic variability in the reproductive cycle of Serbian spruce. The interaction of environmental characteristics and genotypes of extreme and average trees illustrate the reproductive ability of Serbian spruce on different sites and indicates that this species achieves the coenological and not the ecological optimum at its natural sites. Application of genetic/selection programmes can lead to the production of planting stock of desired and defined properties, which could survive the stress environmental factors, thanks to its morphological and physiological properties.
\end{abstract}

Key words: Serbian spruce, variability, artificial populations.

\section{Introduction}

A great part of the genetic variation and the potentials of Serbian spruce natural populations have been incorporated in several artificial populations in Western Serbia at the site Quercetum fraineto-cerris s.l., Salicetum fragillis s.l., and Pinetum nigre s.l. In this way, it becomes much more available for the research and future utilization. The intensive research of the plantations started with the classification of trees into phenogroups which were considered to be significant for forestry and horticulture. The differences between flowering years, plantations and individual trees in the regularity and abundance of micro- and macro-strobiles are major indicator of genetic variability in the reproductive cycle of Serbian spruce.

The intensive research of the plantations started with the classification of trees into phenogroups which were considered to be significant for forestry and horticulture (Isajev, 1987): 
- Phenogroup 'A' - variety 'borealis', branching very similar to Norway spruce, wide crown

- Phenogroup 'B' - variety 'semidichotomy', without visible biotic and abiotic causes, the spontaneous dichotomy - 'false dichotomy'

- Phenogroup 'C' -variety 'serbica', branching type and habit characteristic of Serbian spruce, narrow-pyramidal crown

- Phenogroup ' $D$ ' - variety 'nana', semi-dwarf, maximal height up to $1.80 \mathrm{~m}$

- Phenogroup ' $\mathrm{E}$ ' - dwarf, maximal height up to $0.7 \mathrm{~m}$

- Phenogroup ' $F$ ' - type 'argentea', needles on current-year and second-year branchlets point upwards giving silvery appearance to the crown

- Phenogroup 'G'- type 'viminalis', current-year and second-year branchlets pendulous $30-50 \mathrm{~cm}$ down the branches.

\section{Material and methods}

The analyses were carried out on the sample of 15 trees from five half-sib lines within five phenogroups (1A3, 1B1, 1C2, 1D1 and 1F7). In January 2006, fresh branchlets with dormant buds were collected and transported to the laboratories of the Department of Phytology, Faculty of Forestry, Technical University of Zvolen, Slovak Republic (Milovanović et al. 2007).

The total genome DNA was isolated from 10 to $20 \mathrm{~g}$ (approximately three Serbian spruce needles) of oven dry plant tissue. DNA isolation was based on the modified protocol for rapid isolation of small DNA quantities from the fresh leaf tissue (Doyle J.J., Doyle J.L., 1987).

The internal fragment of the second intron of the mitochondrial NADH dehydrogenase subunit 1 (nad1) gene was amplified using polymerase chain reaction (PCR). PCR followed the proposal reported by Sperisen et al. (2001), applied to Norway spruce with some modifications of the mixture composition (Table 1). PCR amplification was performed by PTC-100 thermal cycler (MJ Research), total volume $20 \mu \mathrm{l}$, with primers nad1F (5'3'; CTC TCC CTC ACC CAT ATG ATG) and nad1R (5'3'; ACA AAG CCC CTT TGA GGG).

The reproductive ability of Serbian spruce on different sites was done by multi-annual analysis of flowering regularity and abundance, flowering percentage at the level of lines number of trees with micro-strobili, number of trees with macro-strobili, average number of micro-strobili per tree and average number of macro-strobili per tree.

T a b le 1. Mixture content used for PCR.

\begin{tabular}{|l|c|c|c|}
\hline & Starting solution & Final concentration & Quantity in reaction $(\boldsymbol{\mu l})$ \\
\hline Buffer $\left(\right.$ with $\left.\mathrm{MgCl}_{2}\right)$ & $10 \mathrm{x}$ & $1 \mathrm{x}$ & 2.5 \\
\hline $\mathrm{dNTP}$ mix & $5 \mathrm{mM}$ & $100 \mu \mathrm{M}$ & 0.5 \\
\hline Primer nad1F + nad1R & $10 \mu \mathrm{M}$ & $200 \mathrm{nM}$ & 0.5 \\
\hline Taq polymerase $($ Sigma) & $5 \mathrm{U} / \mu \mathrm{l}$ & $0.04 \mathrm{U} / \mu \mathrm{l}$ & 0.1 \\
\hline $\mathrm{H}_{2} \mathrm{O}$ & - & 15.4 & \\
\hline DNA 1:5 & 1 & & \\
\hline Total reaction volume $(\mu \mathrm{l})$ & 20 & & \\
\hline
\end{tabular}

\section{Results and discussion}

The revealing, selecting and defining of different phenogroups within the above three plantations was a significant step in the study of Serbian spruce intra-specific variation, which had previously been characterized as exceptionally uniform. The phenotypic determination of different intra- 
specific varieties and types showed the opposite, and it posed numerous questions on the degree of Serbian spruce genetic diversity, genetic control of the phenotypic expression, the degree of inheritance of characteristic traits and the new revealed potential for further breeding of the species (Isajev, 1991; Isajev et al., 1992).

By the selection of superior genotypes within each phenogroup in plantations, by seed collection and by the establishment of the Godovik orchard, the process was continued aiming at the improvement in the genetic structure of the species. As the characteristic traits were observed also in the orchard, the hypothesis on their inheritance was confirmed.

The Godovik orchard represents the second known generation of individuals whose phenotypic traits correspond to the definition of some of the phenogroups. It was only the inheritance of traits characterizing the phenogroup ' $\mathrm{E}$ ' that was not confirmed in the second generation. Phenogroup ' $\mathrm{E}$ ' is by definition characterized by dwarf individuals, with a height of up to $0.7 \mathrm{~m}$, which is not the case at Godovik orchard where at the age of 20, the trees reach the height of even several metres. The individuals in phenogroup ' $G$ ' are not covered by this research, because the location of their blocks during the sampling period (January 2006) was extremely difficult to access.

Genetic diversity, after NEI $(1973,1976)$, shows a considerable variation across the study phenogroups (Table 2). The highest value of this parameter, which indicates the allele diversity in the gene pool of the analyzed locus within the phenogroup, is found in phenogroup ' $C$ ' $(0.7022)$, in which this value nears the maximum of 1 , which means such a genetic structure of the population in which each randomly selected gene represents a unique allele. The values of genetic diversity of Serbian spruce from the Godovik seedling seed orchard cannot be compared to the values of natural populations, because the polymorphism of nad 1 gene in Serbian spruce has not been researched to date.

The cycle of flower and cone development in Picea omorika is shown in Fig. 1. The observed

T a b l e 2. Genetic variation statistics for nad 1 locus.

\begin{tabular}{|c|c|c|}
\hline Phenogroup & Sample size & Neil's (1973) gene diversity \\
\hline A & 15 & 0.3292 \\
\hline B & 15 & 0.1244 \\
\hline C & 15 & 0.7022 \\
\hline D & 15 & 0.5600 \\
\hline F & 15 & 0.3867 \\
\hline
\end{tabular}

differences of the years of flowering in populations and individual trees, in regularity and abundance of micro- and macro-strobilies, are one of the most significant indicators of genetic variability in Serbian spruce reproductive cycle. The occurrence of bisexual strobiles is a phenomenon of special biological and evolutionary significance and is the extreme form of variability in the generative reproduction of Serbian spruce, Figure 2.

The analyses of regularity and abundance of micro- and macro-strobile formation on Serbian spruce trees shows a higher variability of these characters than the variability of phonotypical traits. The number of trees that flowered each year as well as the number of formed strobiles was variable. He highest percentage of trees that flowered compared to the total number of trees was in the population at the site Salicetum fragillis s.l. 


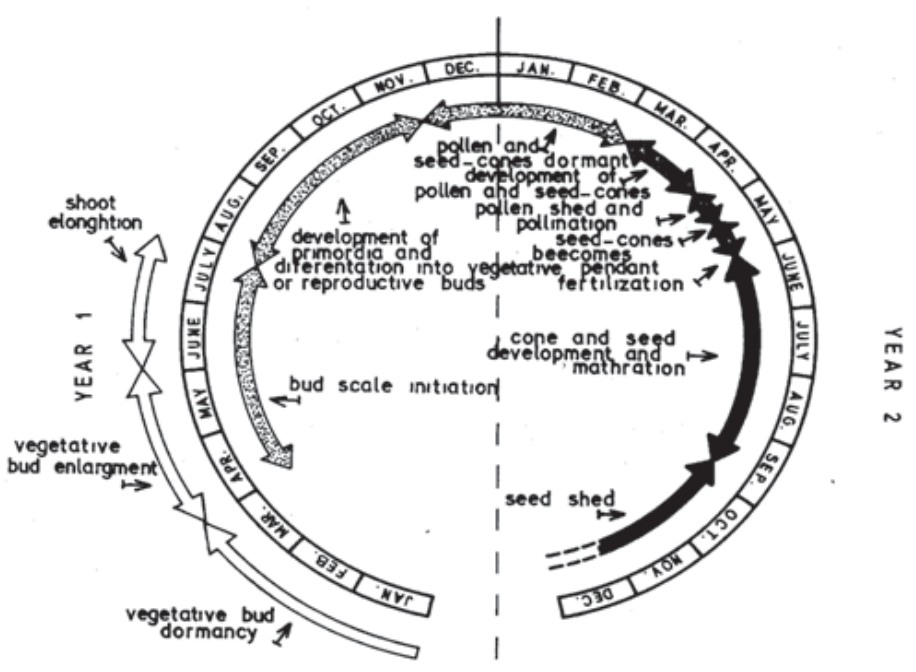

THE CYCLE OF FLOWER AND CONE DEVELOPMENT IN PICEA OMORIKA

Fig. 1. The reproductive cycle in Picea omorika.

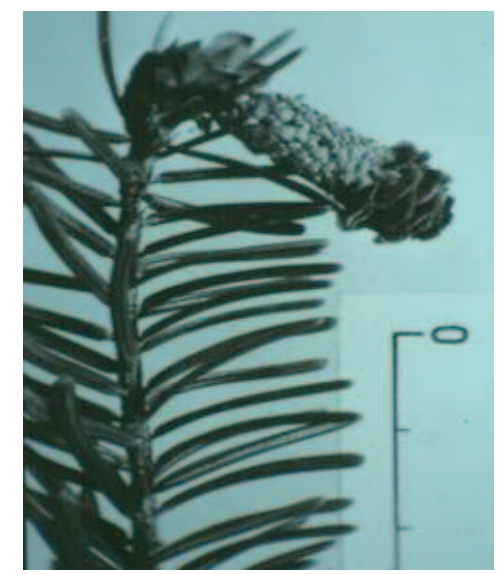

Fig. 2. The occurrence of bisexual strobiles in Serbian spruce (Photo: Isajev,V.).

Based on the above, the Serbian spruce intra-specific differentiation can be compared to the process of allopatric speciation (Chiras, 1991). Due to the geographic isolation and sharp changes of environmental conditions, the former widespread Serbian spruce populations started to divide. The small populations fragmented gradually, colonized the most favourable sites and thus became separated by ecologically unfavourable areas. The period of isolation was followed by the fragmentation into still smaller populations, or the so-called demes (Gilmour, Gregor, 1939). 
The phenotypic traits essential for the designation of the above varieties and types, to some extent, point to the ecological conditions to which the small, isolated populations were exposed. The individuals of the phenogroup ' $C$ ' remained on the typical Serbian spruce sites, steep rocks and deep gorges with deep snow cover, and kept the characteristics of the typical habit, grand height, narrow, pyramidal crown and short branches. Phenogroup 'A' consists of trees with wide crowns and with branching similar to Norway spruce, which points to their existence in the mixed stands with Norway spruce where, by widened crowns, they struggled against the competition of the admixed species. Taking into account the high capacity of Serbian spruce for inter-specific hybridization with the species in Picea genus (Roulund, 1971; Vidaković, 1963), and the fact that Serbian spruce most often occurs in the mixed stands with Norway spruce, it can be inferred that the individuals in phenogroup ' $\mathrm{A}$ ' represent inter-specific hybrids of spruce and Serbian spruce. This hypothesis should be researched by further study of maternal genome variation of both species, but the molecular analyses should also be performed, which would elucidate the inter-specific variation, as well as the characteristics of the paternal genome (chloroplast DNA). The dichotomy of trees in phenogroup 'B' can be related to the former intensive influence of some biotic or abiotic factors which caused the death of the apical bud. The trees developed the defence mechanism and kept it after the disappearance of the causal agent. Variety ' $\mathrm{D}$ ' is characterized by semi-dwarf trees, with height up to $1.8 \mathrm{~m}$, which is probably the consequence of extremely poor site conditions (deep shade, high level of nitrogen in the soil), in which the height increment was significantly reduced. The silvery crown appearance of the individuals in phenogroup ' $\mathrm{F}$ ', which is the consequence of the needles pointed upwards on current-year and second-year branchlets, is most likely the response to the high air humidity, high precipitation sum and deep snow cover. The greatest number of stomata, which enable the transpiration and ventilation, occurs in the lower epidermis, which caused the modification of the direction of needle growth.

\section{Conclusion}

Serbian spruce trees, incorporated in the plantations, can be considered as the indicators of intra-specific variation. Each phenogroup is characterized by a specific habit, which can be considered hereditary, as it is present already in two known generations in different ecological conditions. Consequently, the hypothesis on the genetic determination of the specific phenogroup traits is fully justified.

Based on the results of the analysis of allele polymorphism of nad 1 gene of the mitochondrial genome, it can be concluded that there is a degree of genetic control of phenotype expression in different Serbian spruce phenogroups. This form of intra-specific variation could be explained by the adaptive-ecological phenomena, whose genetic determination has not been completely explained yet, but it exists. Based on the genetic distance from the other phenogroups, the phenogroup 'A' can be supposed to represent the inter-species hybrid of Serbian spruce and Norway spruce, which opens a new topic for the future research of Serbian spruce intra-specific variation.

The study results indicate that only a part of the Serbian spruce variability is visible and that the greater part of the variability is hidden, thanks to various genetic mechanisms. Application 
of genetic/selection programmes can lead to the production of Serbian spruce planting stock of desired and defended properties, which could survive the stress environmental factors, thanks to its morphological and physiological properties

The study results presented are significant for the closer investigation of the genetic structure of this endemic and relic species. The study of the Serbian spruce genetic map is a contribution to the research directed towards the elucidation of the nature of the causes of Serbian spruce genetic specificity, as well as to the selection of the suitable methods for the conservation of its diversity during the process of global environmental changes.

\section{Acknowledgements}

This paper was realized as a part of the project 'Studying climate change and its influence on the environment: impacts, adaptation and mitigation' (43007) financed by the Ministry of Education and Science of the Republic of Serbia within the framework of integrated and interdisciplinary research for the period 2011-2014.

\section{References}

Avice, J.C. (1994). Molecular markers, natural history and evolution. New York: Chapman and Hall.

Ballian, D., Gömöry, D., Longauer, R., Mikić, T. \& Paule L. (2005): Izoenzimska analiza uključujući problem reprodukcije i konzervacije, populacija Pančićeve omorike (Picea omorika Panc./Purk.) sa višegradskog područja. Glasnik Šumarskog Fakulteta Univerziteta u Banjoj Luci. Banja Luka, 3: 23-34.

Ballian, D., Longauer, R., Mikić, T., Paule, L., Kajba, D. \& Gömöry D. (2006): Genetic structure of a rare European conifer, Serbian spruce (Picea omorika (Panč.) Purk.). Plant Syst. Evol., 260(1), 53-63. DOI: 10.1007/s00606-0060431-z.

Chiras, D. (1991): Environmental sciences: action for a sustainable future. Redwood City: Benjamin-Cummings Publ. Co.

Doyle, J.J. \& Doyle J.L. (1987). A rapid DNA isolation procedure for small quantities of fresh leaf tissue. Phytochemical Bulletin, 19: 11-15.

Gilmour, J.S.L. \& Gregor J.W. (1939): Demes: a suggested new terminology. Nature, 144, 333. DOI:10.1038/144333a0.

Isajev, V. (1987): Oplemenjivanje omorike (Picea omorika (Panč.) P u rk.) na genetsko selekcionim osnovama. Doktorka disertacija, Šmarski fakultet, Beograd.

Isajev, V. (1991). Serbian spruce (Picea omorika (Panč.) Purkyne) flowering and seed bearing in seed plantations of Western Serbia (Yugoslavia) - L. Arbre - Biologie oe Development. Naturalia Monspeliensis n. h. s., 616-618.

Isajev, V. \& Dormling I. (1992): Photoperiodic control of growth and growth cessation in 30 half sib families of Serbian spruce seedlings (Picea omorika (Panč.) Purkyne) Genetika, 24(3), 209-217.

Milovanović J., Isajev, V., Krajmerova, D. \& Paule L. (2007): Allele polymorphism of Nad1 gene of the Serbian spruce mitochondrial genome. Genetika, 39(1), 79-91.

Nei, M. (1973): Analysis of gene diversity in subdivided populations. Proc. Natl. Acad. Sci. U.S.A., 70, 3321-3323.

Nei, M. (1976): Mathematical models of speciation and genetic distance. In S. Karlin \& E. Nevo (Eds.), Population genetics and ecology (pp. 723-764). New York, San Francisco, London: Academic Press Inc.

Roulund, H. (1971). Observation on spontaneous hybridization in Picea omorika (Panč.) Purkyne. Arboretum Horsholm Akademisk Forlag Kopenhavn, Biblider.

Tucović, A. \& Isajev V. (1986). Generativna semenska plantaža omorike. Izvođački projekat. OOUR Institut za šumarstvo, Šumarski fakultet. Beograd.

Vidaković, M. (1963). Međuvrsno ukrštanje Pančićeve omorike (Picea omorika (Panč.) Purkyne) sa sitkanskom smrčom (Picea sithensis (B ong.) Cariére). Šumarstvo, 337-342. 